\title{
Macroeconomic factors and firm's cross-border merger and acquisitions
}

\begin{abstract}
This study investigates the impact of macroeconomic variables on the wealth effects of crossborder acquisitions by Malaysian multinational companies. The sample consists of 159 crossborder acquisitions by Malaysian MNCs bidding in 22 countries around the world from 2000 to 2007. The macroeconomic variables examined in this study are foreign economic condition, GNP correlation between countries, and level of economic development of target country. The findings indicate that, foreign economic condition affects the wealth effect negatively, while the level of economic development of target country affects the wealth effect positively. Aside from the macroeconomic variables, we also find that English or nonEnglish language, governmentôs rules index and the telecommunication infrastructure all play certain roles in the Malaysian cross-border acquisitions. Implied from this study is that, value creation of the Malaysian cross-border acquisitions is a function of the foreign economic condition and the level of economic development of the target foreign country.
\end{abstract}

Keyword: Cross-border acquisitions; Event study; Gains from international diversification; M\&A; Malaysian MNC 